Revue Française de Civilisation Britannique

\title{
Cross-Channel Welfare Chauvinism: Backlash from Above and Below
}

Ressentiment racial et État providence en Grande-Bretagne et en France : audelà des approches top-down et bottom-up

\section{Olivier Esteves}

\section{OpenEdition}

\section{Journals}

Electronic version

URL: http://journals.openedition.org/rfcb/6827

DOI: $10.4000 / \mathrm{rfcb} .6827$

ISSN: 2429-4373

\section{Publisher}

CRECIB - Centre de recherche et d'études en civilisation britannique

\section{Electronic reference}

Olivier Esteves, «Cross-Channel Welfare Chauvinism: Backlash from Above and Below », Revue Française de Civilisation Britannique [Online], XXV-4 | 2020, Online since 13 October 2020, connection on 24 October 2020. URL : http://journals.openedition.org/rfcb/6827 ; DOI : https://doi.org/10.4000/rfcb. 6827

This text was automatically generated on 24 October 2020

\section{c)}

Revue française de civilisation britannique est mis à disposition selon les termes de la licence Creative Commons Attribution - Pas d'Utilisation Commerciale - Pas de Modification 4.0 International. 


\title{
Cross-Channel Welfare Chauvinism: Backlash from Above and Below
}

\author{
Ressentiment racial et État providence en Grande-Bretagne et en France : au- \\ delà des approches top-down et bottom-up
}

Olivier Esteves

1 It is generally estimated that the phrase "welfare chauvinism" was coined in a 1990 sociology article on the radical right in Norway and Denmark, i.e. when was ushered in an age of neo-liberal welfare State rollback combined with increasing immigration and ethnic diversity. ${ }^{1}$ In this paper, I want to interrogate this concept in both France and England, both before and since the phrase emerged. As a major predictor of radicalright voting, welfare chauvinism has been at the heart of the FN / RN emergence and so-called dédiabolisation in France, ${ }^{2}$ as well as central to the Brexit vote in England. ${ }^{3}$ The reference to "above" and "below" in the title suggests that to unpack the dynamics of welfare chauvinism in both countries, I will draw from top-down populist discourses as well as from welfare chauvinist interpellations of the ruling elites by self-defined "whites", "citizens", "Britons" or "French", "deserving taxpayers" who "have had enough". The present paper cannot possibly claim to be exhaustive on that complex, multifaceted question, tackling as it does two countries over a half-century. Its somewhat tentative nature is therefore an invitation to further, more comprehensive research on an issue of ever-increasing import in liberal democracies. Ideally, this research should mobilise comparable sources for each country, a very arduous task in itself. Ideally too, quantitative and qualitative data ought to be combined, each taken discretely being insufficient in themselves. 


\section{Top-down instrumentalisation of ethnocentric masses and / or bottom-up interpellations of out-of-touch elites?}

Polemics around the "racism" of the white working-classes are nowhere near ending. On both sides of the channel, media and political discourses on autochthonous working-classes as vociferously disapproving of ethnic diversity and being resentful of immigrants and ethnic minorities that jump the queue of welfare provision have become somewhat routine, particularly at election times. Sometimes, these take the form of miserabilist discourses that whet inter-community feuds all the better to divide and conquer vulnerable classes that, in actual fact, happen to share so much. ${ }^{4}$ Sometimes, the working-classes are pathologized into the "left-behind" or "left out", resentful classes, whose espousal of backlash politics coheres with classical views of racism as stemming from individual, troubled minds. ${ }^{5}$ Sometimes too, such views are in sync with classical interpretations of ethnocentric masses that are informed by the "authoritarian personality" of Adorno et $a^{6}$, although, it has to be said, these interpretations are now largely dismissed in academia. ${ }^{7}$

In Britain, some commentators (Linsey Hanley, Reni Eddo-Lodge) ${ }^{8}$ have been critical of the manufacturing of populist backlash by dint of references to the white working-class, as though non-whites, whether born in London or Lagos, were ontologically removed from the bounds of tax-paying, deserving, hard-working ordinariness. ${ }^{9}$ These points have been made quite convincingly in academia too, be it by historians (Jon Lawrence) ${ }^{10}$ or sociologists (David Gillborn). ${ }^{11}$ In France, analogous critiques have been voiced, particularly by activists and scholars on the "Roma question" (Eric Fassin) ${ }_{12}^{12}$ on eliteconstructed discourses on Muslim Otherness (Marwan Mohammed, Abdellali Hajjat) ${ }^{13}$ as well as on the mainstreaming of far-right perception frames by reactionary forces. ${ }^{14}$ Likewise, some colleagues have been critical of the frequent invocation of "Front National, premier parti ouvrier" which tends to downplay the importance of abstention in elections as well as to validate the pathologisation of the working-classes as inherently driven by irrational, "racist" passions. Some of these writings also shed crucial, critical light on the far-right's "populism" in France (Annie Collovald, Violaine Girard). ${ }^{15}$ Empirically, Stéphane Beaud and Michel Pialoux have also argued that "l'analyse en soi d'un 'racisme ouvrier' n'a pas grand sens parce qu'elle procède, fondamentalement, par abstraction des conditions sociales d'existence du groupe ouvrier $» .^{16}$

In broad terms, a large portion of the qualitative studies ${ }^{17}$ of far-right populism are either externalist approaches, which lay stress on propaganda, brochures, and more generally speaking on the economic, social, attitudinal, or cultural environments of the radical-right. Internalist approaches are fewer in number, for "data from interviews with members, observations of group activities, and internal documents are difficult to obtain". ${ }^{18}$ They are generally ethnographies of the far-right (Hilary Pilkington in England, Daniel Bizeul in France) or of white backlash responses to ethnic diversity (Roger Hewitt or Justin Gest in London, Michelle Lamont in the Paris outskirts) which apprehend populism in terms of grassroots interpellations of the elites. In fact, sociologist Paul Mepschen, who carried out ethnographic research into backlash responses in a working-class area of Amsterdam, suggests a broadening of the category 
of "populism", in order to embrace bottom-up "processes of articulation, interpellation, and [...] agency". ${ }^{19}$ This is what this paper tries to do, if in a limited way.

The fact is that top-down and bottom-up perspectives ought to be considered in constant, complex interaction rather than in strictly exclusive terms. In France, Sylvain Laurens's work on haut fonctionnaires archives has convincingly demonstrated that elite anxieties over grassroots feelings actually led directly to the closing of national borders in $1974,{ }^{20}$ thereby anticipating -but also cultivating- the nativist backlash that was to set in by the next decade, particularly with the consecutive Front National breakthroughs at the elections of 1984, 1985, 1986. In Britain, the Labourite slogan on immigration "without integration, limitation is inexcusable; without limitation, integration is impossible" was both an elite, paternalistic exhortation in favour of "racial harmony" at grassroots level as much as an elite pandering to local anxieties over immigration in the wake of the nativist backlash during the 1964 general elections.

6 The archival material which partly sustains this paper, i.e. letters of support to Enoch Powell, also provides a powerful challenge to the top-down vs bottom-up binary. This is because, after his Walsall speech of February $9^{\text {th }} 1968$, the Midland Tory was astonished to have received some 800 letters of support, from which he drew the rhetorical, backlash fodder for his next speech, the Birmingham speech, routinely labelled 'Rivers of Blood' ${ }^{22}$ In the following fortnight, he received some 100000 letters, overwhelmingly in support.

7 Powell's speech was therefore a public performance (in Goffman's sense) ${ }^{23}$ of radical right populism echoing, and in so doing framing, exacerbating, indeed uninhibiting, some grassroots perceptions, feelings, injustice frames. These had been simmering since the 1960-1962 large-scale non-white immigrant influx, and the 1964 general elections, particularly at Smethwick, sometimes dubbed "Britain's most racist election". ${ }^{24}$ Instead of merely identifying Powell as a populist and focusing exclusively on his rhetoric, his political style, his ideology and his strategic marginality within the conservative party, it is preferable to apprehend his campaign against immigration from the point of view of a -discursively efficient- asymmetrical ritual of interaction, wherein disgruntled constituents confide to their political hero their backlash personal narratives, which he would rhetorically exploit in his next speeches.

8 It is also noteworthy for the purpose of this contribution that nowhere in his $1968 \mathrm{did}$ Powell overtly refer to non-white immigrants as undeservedly getting welfare assistance of any sort. And yet, the backlash correspondence he received was overwhelmingly in the form of welfare chauvinism. This is copious evidence, as has been suggested by Camilla Schofield, of the ways in which the Wolverhampton M.P. conferred political respectability to feelings and perceptions hitherto deemed impossible to verbalise. To be sure, the private mode of communication -letter-writingmade it easier to communicate certain prejudices, especially to a person deemed a political friend, or hero. The many thousands of welfare chauvinist responses he received and the fact that he never explicitly expressed those views is interesting in itself, and suggests that these perception frames had been embedded in British public opinion before 1968, but had remained somewhat politically dormant. Elizabeth Buettner has unveiled some of these perceptions by focusing on Smethwick in 1964, notably by mobilizing letters to the editor in the local press, particularly to a newspaper, The Smethwick Telephone and Warley Courier, that was quite ready to vocalize 
the local backlash responses. ${ }^{25}$ If anything, the disconnect between top-down discourses (explicitly) devoid of welfare chauvinist references and bottom-up outpourings replete with welfare chauvinism tends in itself to nuance, if not to challenge, the binary analysed here.

\section{Forms and degrees of welfare chauvinism}

9 "Welfare chauvinism", according to Herbert Kitschelt, is an attitude among those who support "a system of social protection [only] for those who belong to the ethnically defined community and who have contributed to it". ${ }^{26}$ Welfare chauvinist perceptions are overwhelmingly conditioned by perceptions of deservingness, whose contours are delineated by three elements : identity (the extent to which recipients belong to a common identity) ; attitude (the extent to which they are grateful for the help) ; reciprocity (the extent to which recipients are ready to help when it is their turn to do so). ${ }^{27}$

10 Although it has been challenged by some scholars, ${ }^{28}$ there is a widely-shared, quite uncontroversial sense that public trust in Welfare redistribution tends to rest on a broad assumption of likeness : the stronger the sense of imagined community within a nation, the more likely taxpayers will be to acquiesce to tax schemes funding schools, hospitals, unemployment benefits, etc. Etienne Balibar has used the phrase "preferential altruism", ${ }^{29}$ which is quite apposite here. After all, the great state-builders at the root of welfare provision (T. H. Marshall, William Beveridge, Gunnar Myrdal in Sweden) hardly believed otherwise..$^{30}$ For one, T. H. Marshall argued in 1950 that consent to welfare help was predicated on a "direct sense of community membership based on a loyalty to a civilization that is a common possession". ${ }^{31} \mathrm{At}$ the international level, the language in use reflected such boundaries : Frederick Cooper, for one, has written on the important connections between "development" as a goal of the British Colonial Office and "welfare" -so key to British politics by 1940, thereby confirming demarcation lines between the metropole and the Empire / Commonwealth. ${ }^{32}$

As may be expected, racialisation discourses in all their forms tend to exacerbate welfare chauvinism. "Racialisation" is here loosely understood in the sense of underlining the Otherness of social groups who in many cases share the citizenship of the majority group. This may consist in labelling as "immigrants" communities that are not "immigrants", or in referring to groups as "second generation immigrants", "Maghrébins", etc. It may also consist in foregrounding the cultural incompatibility of certain communities. For instance, when on June 19th 1991, at a "dîner-débat» of his Gaullist political party (the now defunct RPR) in Orléans, Jacques Chirac exposed « le bruit et l'odeur » ('the noise and the smell') of certain large families in the Goutte d'Or neighbourhood of Paris (well-known for being a multicultural and disadvantaged area), $r$, he was not delivering a welfare chauvinist speech as such, but his invocation of autochthonous deservingness and respectability faced with the cultural, radical Otherness of supposedly thankless immigrants was certainly conducive to legitimizations of welfare chauvinist invectives. More subtly these recent years, the FN / RN's harnessing of « laïcité » and the suggestion that Muslims are demanding special rights (instead of just being in line with freedom of religion as guaranteed in the 1905 separation of Church and State) ${ }^{33}$ certainly legitimizes welfare chauvinist narratives as well. This, albeit in an oblique way, echoes what Kymlicka and Banting have called the 
politics of recognition / politics of redistribution trade-off. The politics of recognition in the form of multiculturalism, with differential treatment of specific groups within society, seem to clash the universalistic dimension of Welfare distribution.

My research on the Powell letters has unveiled three categories of welfare chauvinism which appear as master frames overlapping to some degree. The first two are projected as "common sense" viewpoints which often make it possible to stave off accusations of "racialism" ${ }^{34}$ The third is explicitly offensive.

First, demographic welfare chauvinism. This is about strains on social services generated by the large number of immigrants, particularly in the field of education (primary schools) and of health (maternity wards). It is partly predicated on a silencing of old-age pensions, since immigrants are young and old-age social schemes do not concern them at all. Although some immigrants (Pakistanis) were notorious taxshirkers, claiming allowance for non-existent children back in Pakistan, ${ }^{35}$ it is a fact that with benefits and costs taken together immigrants brought -and still bring todaymore to the State finances ${ }^{36}$ as well as to the economy than they took.

Sometimes, these welfare chauvinist responses informed local policies. Worried about the immigrant strain on the local housing market, the communist mayor of Vénissieux (housing estate to the east of Lyon) initiated, in the early 1980s, a policy of seuil de tolérance in practice by deliberately keeping vacant flats in his town rather than make them available for immigrant families, all in an effort to keep the autochthonous established working-classes and the middle-classes in the area. ${ }^{37}$

15 Second, "Length of residence welfare chauvinism". This is a rarer type of narrative, which lays stress on immigrants as newcomers, and never refers to them as British citizens or taxpayers. Length of residence is seen as conferring legitimacy to claim welfare provision, through what may be called a kind of autochthonous capital. In such discourses tax is central.

Thirdly, "stigmatizing welfare chauvinism". In this very recurrent narrative, immigrants are vilified as "scroungers", "parasites", whose presence in Britain is mostly (or solely) owed to welfare generosity. Below are a few examples of such invectives from Powell's postbag in 1968 :

"Let's face it, the immigrants do not come out of any love for Britain, but for our Welfare State, which has been the ruination of our country" (Man, Chesshire).

"With these benefits gone the inflow of coloured people would cease. They only come to get something for nowt" (constituent from Hatch End, Middlesex).

"The time for GIVING has to stop, now they should start to contribute to the country they hate so much they can't bear to leave" (woman, Reading).

"The only magnet drawing immigrants here is the extraordinary insane generosity of the greatest international charity ever : the Welfare State" (constituent from Manchester).

"Immigrants [...] can safely be expected to become parasites and unproductive members of our society" (Constituent from Bushey Heath (Hertfordshire)).

"The welfare state is the new Eldorado for these people, who can live comfortably without working, on the 'hand-outs' of the welfare state" (man, Stoke-on-Trent). ${ }^{38}$

The White politics of belonging ${ }^{39}$ were sometimes consolidated in more inventive ways. Such was the case with those factory poems ostracizing immigrants as "welfare parasites". Tellingly, some of these echo each other, in a national string of popular verse fuelled by a complex skein of gossip and rumours. ${ }^{40}$ Although the writing skills displayed therein fuel a very local type of pride, like some football chants from 
Bournemouth to Aberdeen, they are in fact remarkably alike across the country. Whole stanzas are identical, using deprecatory, homo-social humour as a discursive shield to make sense of a perceived threat, replete with references to the "dole", which is itself constantly racialised. What follows was sent by nine factory workers in Lancashire and is entitled "England my England", but almost the same poem was sent from Glasgow as well as from some unidentified place in England:

I come to England, poor and broke, go on dole, see labour bloke / Six months on dole, got plenty money, good fresh meat to fill my tummy / Send for friends in Pakistan, tell them come quick as can / Plenty of us on the dole, lovely suit and big bank roll/ National assistance is a boon, all dark men on it soon. ${ }^{41}$

In an immensely popular TV show which purported to expose racist stereotypes, the main character, cockney bigot Alf Garnett, regularly inveighed against immigrants, whom he inevitably dismissed as "welfare scroungers". ${ }^{42}$ If anything, this speaks volumes about the extent to which these offensive badges were deeply rooted some fifty years before Brexit. This was a post-colonial hangover to some extent, stemming from fancied visions of "African sloth" ${ }^{43}$ indigenous peoples whose tropical climates made them inherently reluctant to work, etc. The climate element was also sometimes invoked as immigration's raison d'être : the idea that the weather was so inclement in Manchester or Newcastle that non-whites from Bombay or Kingston could only be attracted by welfare bonanzas, an idea expressed frequently in Powell's postbag.

Such archival sources are not to be found in France, and if they do exist, to a much more limited degree, they are very hard to come by. The Front National / Rassemblement National is notoriously secretive about their archives, although the party is known to treat scholars quite differently from the way they deal with journalists. ${ }^{44}$ Letters to the editor sent to Minute (created in 1962) and Rivarol (founded in 1951) might provide some information about far-right grassroots backlash against those perceived as "undeserving" immigrants, but the nature of the sources is (very) different from Powell's postbag, ${ }^{45}$ and the readership of both publications is much more limited than the cross-class, cross-party, indeed kaleidoscopic backlash that informs the 1968-9 epistolary support to the Wolverhampton demagogue. One other solution would be to unveil constituent letters to municipalities in well-known areas of ethnic minority and immigrant clustering, in Seine Saint Denis, or around Lyon and to the north of Marseille. Much of this research remains to be done.

\section{The rootedness of English welfare chauvinism, an exception in Europe?}

In the $21^{\text {st }}$ century, there is quantitative evidence suggesting that, in the UK, welfare chauvinism itself is somewhat stronger than in France. Yet, in itself it remains quite unexceptional by European standards, if quite high when compared with other Western or Northern European nations. The European Social Survey analysed by Stevan Svallfors, based on 34947 interviews across some $28 \mathrm{EU} /$ non EU European countries, unpacks the intensity of welfare chauvinism with the question "“"when should nonnationals start being allowed to get welfare provision ?". The most liberal option is "immediately on arrival". There are then various categories down to the very end, "they should never get welfare provision", which is itself the strongest indicator of a welfare chauvinist attitude. A selection of some 10 countries from the 28 has been 
reproduced in Table 1, which highlights but also nuances the UK's exceptionalism as far as welfare chauvinism is concerned. The UK displays levels which are reasonably higher than France's, and much higher than Sweden's. Nevertheless, the UK figures are slightly below Russia's and much below Turkey's, in a study carried out before the European migrant crisis, whose effects were felt much more keenly in Turkey than they were in the U.K.

\begin{tabular}{|c|c|c|c|c|c|}
\hline Country & $\begin{array}{l}\text { Immediately } \\
\text { on arrival }\end{array}$ & $\begin{array}{l}\text { After a year, } \\
\text { whether or not } \\
\text { they have } \\
\text { worked }\end{array}$ & $\begin{array}{l}\text { After worked } \\
\text { and paid taxes } \\
\text { for at least a } \\
\text { year }\end{array}$ & $\begin{array}{l}\text { Once they } \\
\text { have } \\
\text { become } \\
\text { citizens }\end{array}$ & $\begin{array}{l}\text { They should never } \\
\text { get the same rights } \\
\text { (welfare chauvinism) }\end{array}$ \\
\hline $\begin{array}{l}\text { Czech } \\
\text { Republic }\end{array}$ & 2.4 & 5.5 & 35.1 & 42.1 & 14.9 \\
\hline France & 12.2 & 10.7 & 47.0 & 25.1 & 5.0 \\
\hline Germany & 8.4 & 11.8 & 43.4 & 29.9 & 6.5 \\
\hline Netherlands & 7.8 & 9.7 & 35.2 & 44.5 & 2.8 \\
\hline Russian Fed. & 4.8 & 5.0 & 31.7 & 46.2 & 12.3 \\
\hline Spain & 11.4 & 9.2 & 52.1 & 21.7 & 5.6 \\
\hline Sweden & 19.8 & 16.2 & 31.1 & 32.1 & 0.7 \\
\hline Switzerland & 12.5 & 12.9 & 56.1 & 15.7 & 2.9 \\
\hline $\begin{array}{l}\text { United } \\
\text { Kingdom }\end{array}$ & 5.6 & 5.4 & 48.6 & 31.5 & 8.9 \\
\hline Turkey & 10.0 & 10.2 & 18.9 & 41.9 & 19.0 \\
\hline
\end{tabular}

Table 1 Source : European Social Survey, 2008-9, 34947 respondents in 28 E.U. and non E.U. European countries, printed in Stevan SVALLFORS (ed.), Contested Welfare States, Welfare Attitudes in Europe and Beyond, Stanford (Cal.) : Stanford University Press, 2012, p. 137-8.

The relative strength of welfare chauvinism in the U.K. might stem from several structural causes : a Welfare State which is more weakened than in other countries due to decades of roll-back, a super-diversity which is higher than in other European countries, and the particularly visible influence of the conservative, backlash media. ${ }^{46}$ At this stage, however, further research would be necessary to fully evaluate the relevance of these potential explanatory factors.

More broadly speaking, some reservations may be expressed about this type of ? European survey. First, and following Bourdieu's 1972 lecture «L'opinion publique n'existe pas " ('public opinion does not exist'), opinion polls generate the illusory impression that all people ask themselves the same questions in the same terms at the same time by asking the same questions to every respondent, thereby creating what 
Bourdieu calls a "consensus effect" (effet de consensus). ${ }^{47}$ Then, opinion polls perniciously invite respondents to answer questions they did not necessarily ask themselves in the first place. Worryingly in the present case, asking that specific question seems to validate the fact that immigrants themselves are, as it were, inherently motivated by getting welfare help, and not just by working, finding a place to live where they are safe from harm, etc. On top of this, asking the same question to Swedish people as well as to Russian and Turkish people also seems to validate the fact that Welfare State provision is comparable across European nations, which it so very obviously is not.

Be that as it may, the European Social Survey does suggest that Welfare Chauvinism is stronger in Britain than in France, and the reasons for this have inevitably to do with the fact that welfare chauvinist attitudes of the type analysed in postbag Powellism is (much) more deeply entrenched historically, and this beyond the structural causes ventured above. In the mid-1960s, as we have briefly seen, such perception frames explaining the non-white immigrant presence were almost routine among ethnocentric Britons, both within urban sites of ethnic clustering as well as in areas with no known history of immigration at all, for instance in the southern villages of Devon, Cornwall, Dorset. $^{48}$

As opposed to this, only by the early 1980s would welfare chauvinist responses really start to crystallize in France. Certain lengthy ethnographies of working-class life do not at all refer to the immigrant presence as a threat on the job market, or as a strain on welfare services, although the dole queues were inexorably lengthening through systemic deindustrialization. In this respect, Olivier Schwarz's Le Monde privé des ouvriers based on a five-year immersion in the bassin minier (translate into English) around Hénin-Beaumont and Lens is a very apposite example. ${ }^{49}$ Within the work on Front National edited by Nonna Mayer and Pascal Perrineau, a mid-1980s ethnographic fieldwork on 132 Front National voters in the Paris and Bordeaux banlieues pays very little attention to welfare chauvinism, with only one 50-year old man from Les Ulis (Essonne) arguing that he is sick and tired of contributing, via his council tax (impôts locaux) to the financing of the local mosque as well as to Portuguese language classes so that children of immigrants may go back home. ${ }^{50}$ Most of the other nativist backlash is expressed in terms of "numerological racism", ${ }^{51}$ of the type "there are too many immigrants and we don't feel at home any longer", or the "cultural inherentism" type, ${ }^{52}$ expressed in terms of "their culture is too different and they can't be assimilated". It may therefore be conducive to welfare chauvinism without being overtly welfare chauvinist per se. Front National rhetoric and propaganda, particularly as it appeared on posters, presented itself in terms of nativist, economic common-sense on the job market, such as with the very well-known : "Un million de chômeurs c'est un million d'immigrés de trop " (one million jobless is one million immigrants too many) in the 1980s which had become, one decade later, the same sound-bite but with "three millions" instead. ${ }^{53}$ Officially, instead of presenting so-called "immigrants" as sponging off welfare bonanzas, these were presented as a threat on the job market, and a cultural, civilizational threat with an increasing focus on the radical Otherness of Islam. In bottom-up terms, the "parasitic argument" against immigrants and ethnic minorities as "scroungers" started to be more openly and systematically expressed by the 1990s, as was evidenced in Michelle Lamont's early 1990s ethnography at the periphery of Paris. One Ivry man vituperated : "Parasites....I hate all of them. All those 
people that don't have a sense of responsibility [...] I am very familiar with them. They don't work. They only know the way to the unemployment insurance office, the ASSEDIC [the acronym for this office, which he pronounces with a North African accent]". ${ }^{54}$ Very often though, welfare chauvinist responses were couched in more inarticulate, cautious terms, highlighting the priority to foster solidarity among nationals rather than with non-nationals, as is evidenced here with Emmanuelle Comtat's ethnographic fieldwork among pieds-noirs : "Quand on dit les lois sociales pour les Français, je dis d'accord. Quand on dit, les immigrés, bon, s'ils veulent venir pour travailler, autrement qu'ils restent chez eux $\gg .{ }^{55}$

To a large extent, the Front National programmatic sea-change in the course of a generation epitomizes the new centrality of welfare chauvinism. Indeed, one of the main shifts between Jean-Marie Le Pen (until 2000) and Marine Le Pen (since 2000) has been what Cécile Alduy has rightly labeled le virage étatique. ${ }^{56}$ Whereas Jean-Marie Le Pen was an unreserved supporter of Reaganite Welfare roll-back in the 1980s, Marine Le Pen has time and again foregrounded the pivotal function of the State, be it in terms of law and order but also in terms of social services. Indeed, les services publics is the third noun clause that is most often used in her speeches as analysed by Alduy and Wahnich. ${ }^{57}$ The State in her rhetoric is deemed a national bulwark against the evil forces of corporate and cosmopolitan "mondialisme ", whatever this word might mean. And this State could primarily cater to the dire needs of nationals. Marine Le Pen, by invoking Jean Jaurès, places the protective, welfare State at the heart of her agenda in the same way as radical right forces in Britain (the BNP) have presented themselves using the slogan "We're the Labour Party your grandparents voted for" (BNP), or projecting themselves as political forces whose priority was to save the NHS (as UKIP during the Brexit referendum campaign of 2016). Most of these campaigns are either conducive to welfare chauvinist responses, or else directly utilize welfare chauvinism to garner greater electoral support. ${ }^{58}$ Again, as with Powell's speeches and his postbag discussed above, the overlap between discourses that are explicitly or implicitly welfare chauvinist, or else nurturing such perception frames, all tend to challenge neatly-drawn bottom-up or top-down dichotomies.

\section{Conclusion}

In White Identities, A Critical Sociological Approach, Steve Garner and Simon Clarke articulate the view that whereas in decades past there was a widespread feeling among whites that "those people" were coming to "steal our jobs", the general feelings post-2000 is rather that the very same people are perceived as communities who come "to sponge our welfare". ${ }^{59}$ Similar points have been made on the far-right's electoral appeal, particularly in political science works on the B.N.P. ${ }^{60} \mathrm{I}$ want to argue here that such perceptions were already extremely widespread in 1968 , and probably a few years before. Indeed, the violently welfare chauvinist, "parasitic argument" legitimizing racial animus was so much more widespread than the "they steal our job" type of argument, itself quite rare, or often nuanced.

To be sure, this is an exception not only when the rootedness of such perception frames are compared with France, but probably also with the rest of Europe, at least the part of Europe that has a more or less recent history of immigration (say from France to Italy, 
from Belgium to Spain) as well as Welfare redistribution schemes that are part of the warp-and-woof of street-level and national level bureaucracy.

In both countries as elsewhere, welfare chauvinist otherings of immigrants and ethnic minorities, which by contrast reinforce self-perceptions and self-projections of deservingness and of nationals as "disciplined selves", to borrow Lamont's phrase, very often are rooted in a proclaimed personal experience that contrasts with elite invocations of racial harmony, multicultural integration, etc. As Blondel and Lacroix put it in their 1980s fieldwork on Paris and Bordeaux : "L'invocation/ évocation renvoie ainsi à l'expérience immédiate: on n'aura pas été sans remarquer que les propos cités s'appuient sur le lieu d'habitation et qu'ils convoquent, à ce titre, tout un ensemble d'expériences non nécessairement construites intellectuellement qui ont trait à l'espace social des relations quotidiennes $"{ }^{61}$ Similar points have been made by Noiriel in more broadly historical terms ${ }^{62}$ Strange though it might seem, one of the ways in which ethnic minorities and immigrants might manage to counter deep-rooted narratives of welfare chauvinism is by elbowing their way into an ordinariness that is all too often apprehended as "white". In this sense, the recent COVID-19 pandemic provides a glimmer of an answer. The video "You Clap for Me Now"63 went viral on British social networks, unveiling the simple fact that many Britons' lives are indeed daily serviced by socially invisible armies of BAME workers, this nearly four years after Brexit. Only the future will tell whether the many outpourings of cross-ethnic solidarity, the quotidian, friendly interaction with ethnic minority and immigrant staff in hospitals and services in general (garbage collection, etc.) can possibly be combined with radical right support, made all the more acceptable as "welfare chauvinist" frames are growingly removed from the "political" and securely ensconced in the "common sense".

\section{BIBLIOGRAPHY}

\section{Primary sources}

Staffordshire Record Office, Powell Papers, Letters in support bundles D3123/10 ; D3123/14 ;

D3123/15 ; D3123/20 ; D3123/45 ; D3123/57 ; D3123/90.

\section{Press}

Daily Mail

Daily Telegraph

Financial Times

The Guardian 
Libération.

\section{Secondary sources}

ADORNO, T. et al, The Authoritarian Personality, London : Verso, 2019 [1950].

ALDUY, C., WAHNICH, S., Marine Le Pen prise aux mots : décryptage du nouveau discours frontiste, Paris : Le Seuil, 2015.

ANDERSEN, J. G., BJøRKLUND, T., "Structural Change and New Cleavages : The Progress Parties in Denmark and Norway”, Acta Sociologica, Vol. 33 (3), 1990, p. 195-217.

BANTING, K., KYMKICKA, W. (eds.), The Strains of Commitment, Political Sources of Solidarity in Diverse Societies, Oxford : Oxford University Press, 2017.

BIZEUL, D., Avec ceux du FN : un sociologue au Front National, Paris : La Découverte, 2003.

BLONDEL, J., LACROIX, B., « Pourquoi votent-ils Front National ? ", in Nonna MAYER, Pascal PERRINEAU, Le Front National à Découvert, Paris : Presses de Sciences-Po, 1996, p. 150-168.

BOURDIEU, P., Questions de sociologie, Paris : Les Éditions de Minuit, 1984.

BUETTNER, E., “ 'This is Staffordshire not Alabama': Racial Geographies of Commonwealth Immigration in Early 1960s Britain", Journal of Imperial and Commonwealth History, 2014, Vol. 42 (4), p. 710-740.

CARVALHO, J., “The End of a Strategic Opening ? The BNP's window of opportunity in the 2000s and its closure in the 2010s", Patterns of Prejudice, Vol. 49 (3), 2015, p. 271-293.

COLLOVALD, A., Le "Populisme du FN", un dangereux contresens, Bellecombe-en-Bauges : Editions du Croquant, 2004

COMTAT, E., Les Pieds-noirs et la politique : quarante ans après le retour, Paris : Presses de Sciences-Po, 2009.

DEZÉ, A., Le Front National : à la conquête du pouvoir ?, Paris : Armand Colin, 2012.

DEZÉ, A., MAYER, N., CRÉPON, S., Les Faux semblants du front national : Sociologie d'un parti politique, Paris : Presses de Sciences-Po, 2016

EDDO-LODGE, R., Why I'm No Longer Talking to White People About Race, London : Bloomsbury, 2017.

ESTEVES, O., Le Pen, les crèches et le centre commercial de Pawtucket », Libération, 06. 04. 2017.

ESTEVES, O., PORION, S. (eds), The Lives and Afterlives of Enoch Powell : The Undying Political Animal, Abingdon : Routledge, 2019.

FASSIN D., FASSIN, E. De la question sociale à la question raciale ? Représenter la société française, Paris : La Découverte, 2006.

FASSIN, E. et al, Roms et riverains, une politique municipale de la race, Paris : La Fabrique, 2014.

GARNER, S., CLARKE, S., White Identities, A Critical Sociological Approach. London : Pluto Press, 2010.

GEST, J., The New Minority: White Working-Class Politics in an Age of Immigration and Inequality, Oxford : Oxford University Press, 2016.

GILLBORN, D., "The White working-class, racism and respectability : victims, degenerates and interest convergence", British Journal of Educational Studies, Vol. 58 (1), 2010, p. 3-25.

GIRARD, V., Le Vote Front National au village, Bellecombe-en-Bauges : Editions du Croquant, 2017. 
HAGE, G., Continuity and Change in Australian Racism", Journal of Intercultural Studies, Vol. 35 (3), p. 232-237.

HAJJAT, A., La Marche pour l'égalité et contre le racisme, Paris : Amsterdam, 2013.

LAMONT, M. The Dignity of Working Men, Morality and the Boundaries of Race, Class and Immigration, Cambridge (Mass) : Russell Sage Foundation \& Harvard University Press, 2000.

LANGHAMER, C., “ 'Who the hell are ordinary people?' Ordinariness as a category of historical analysis", Transactions of the Royal Historical Society, Vol. 28, 2018, p. 175-195.

LAURENS, S. Une Politisation feutrée : les hauts fonctionnaires et l'immigration en France, 1962-1981, Paris : Belin, 2009.

LAWRENCE, J., Me, Me, Me? The Search for Community in Post-War England, Oxford : Oxford University Press, 2019.

MOHAMED, M., HAJJAT, A., Islamophobie : Comment les élites françaises fabriquent le problème musulman, Paris : La Découverte, 2013.

PILKINGTON, H., Loud and Proud : Passion and Politics in the English Defence League, Manchester : Manchester University Press, 2016.

ROSE, E. J. B (ed.), Colour and Citizenship : Report on British Race Relations, Oxford : Oxford University Press, 1969.

SCHAFFER, G., “' 'Till Death Us Do Apart' and the BBC: Racial Politics and the British Working Classes 1965-75", Journal of Contemporary History, Vol. 45 (2), 2010, p. 454-477.

SCHOFIELD, C., Enoch Powell and the Making of Post-Colonial Britain, Cambridge \& New York : Cambridge University Press, 2013.

SVALLFORS, S. (ed.), Contested Welfare States, Welfare Attitudes in Europe and Beyond, Stanford (Cal.) : Stanford University Press, 2012.

WOOLFE, A., KLAUSEN, J., "Identity Politics and the Welfare State", Social Philosophy and Policy, Vol. 14 (2), 1997, p. 213-255.

YUVAL-DAVIS, N., "Belonging and the Politics of Belonging”, Patterns of Prejudice, Vol. 40 (3), 2006, p. 196-213.

\section{NOTES}

1. Jørgen Goul ANDERSEN, Tor BJøRKLUND, "Structural Change and New Cleavages : The Progress Parties in Denmark and Norway”, Acta Sociologica, Vol. 33 (3), 1990, p. 195-217.

2. See Alexandre DEZÉ, "La dédiabolisation : une nouvelle stratégie ?", in Alexandre DEZÉ, Nonna MAYER, Sylvain CRÉPON, Les Faux semblants du front national : Sociologie d'un parti politique, Paris : Presses de Sciences-Po, 2016, p. 25-50.

3. The choice of "England" rather than "Britain" or "the U.K." is deliberate since backlash politics of the welfare chauvinist type has been largely focused on England, primarily because ethnic and racial diversity is historically rooted in England rather than Britain, despite some local exceptions, which pale into historical and demographic insignificance when compared with English sites of ethnic clustering (London, Birmingham, West Midland and West Yorkshire towns, primarily). 
4. See Kjartan Páll SVEINSSON (ed.), Who Cares About the White Working-Class?, London : Runnymede Trust, 2009 : https://www.runnymedetrust.org/uploads/publications/pdfs/ WhoCaresAboutTheWhiteWorkingClass-2009.pdf

5. On "racism" as springing from "damaged, disturbed personalities", see Ann Laura STOLER, Duress : Imperial Durabilities of Our Times, Durham (N.C.) : Duke University Press, 2016, p. 253.

6. Theodor ADORNO et al., The Authoritarian Personality, London : Verso, 2019 [1950].

7. For a persuasive critique of Adorno et al, see Andrew BONILLA SILVA, Racism Without Racists : Colour-Blind Racism and Racial Inequality in Contemporary America, Lanham (MD) : Rowman \& Littlefield, 2009 [2 $2^{\text {nd }}$ ed.], p. 132.

8. Linsey HANLEY, “This White Working-Class Stuff is a Media Invention”, The Guardian, 30. 05. 2008 ; Reni EDDO-LODGE, Why I'm No Longer Talking to White People About Race, London : Bloomsbury, 2017, 202-206.

9. On the harnessing of ordinariness as a catch-all, political category, see Claire LANGHAMER, “ 'Who the hell are ordinary people?' Ordinariness as a category of historical analysis”, Transactions of the Royal Historical Society, Vol. 28, 2018, p. 175-195.

10. Jon LAWRENCE, Me, Me, Me ? The Search for Community in Post-War England, Oxford : Oxford University Press, 2019, p. 154-155.

11. David GILLBORN, “The White working-class, racism and respectability : victims, degenerates and interest convergence", British Journal of Educational Studies, Vol. 58 (1), 2010, p. 3-4.

12. Eric FASSIN et al, Roms et riverains, une politique municipale de la race, Paris : La Fabrique, 2014, p. 52.

13. Marwan MOHAMMED, Abdellali HAJJAT, Islamophobie : Comment les élites françaises fabriquent le problème musulman, Paris : La Découverte, 2013.

14. CETTE FRANCE LÀ (coll.), Xénophobie d'en haut : le choix d'une droite éhontée, Paris: La Découverte, 2012.

15. Annie COLLOVALD, Le "Populisme du FN", un dangereux contresens, Bellecombe-en-Bauges: Editions du Croquant, 2004 ; Violaine GIRARD, Le Vote Front National au village, Bellecombe-enBauges : Editions du Croquant, 2017.

16. Quoted in Didier FASSIN, Eric FASSIN (eds.), De la question sociale à la question raciale ? Représenter la société française, Paris : La Découverte, 2006, p. 88-9.

17. Quantitative analyses generally rely on nationwide (or cross-national) surveys of electoral surveys before or just after elections.

18. Kathleen BLEE, "Ethnographies of the far-right", Journal of Contemporary Ethnography, Vol. 36 (2), 2007, p. 121.

19. Paul MEPSCHEN, Everyday autochthony : Difference, discontent and the politics of home in Amsterdam, Phd dissertation, University of Amsterdam, 2016, p. 64.

20. Sylvain LAURENS, Une Politisation feutrée : les hauts fonctionnaires et l'immigration en France, 1962-1981, Paris: Belin, 2009 ; Sylvain LAURENS, « 1974 et la fermeture des frontières. Analyse critique d'une décision érigée en turning-point ", Politix, vol. 21 (82), 2008, p. 67-92.

21. The phrase was used by Roy Hattersley, MP for Sparkbrook, one of the most multiracial constituencies in the country. It epitomizes the contents of the August 1965 White Paper on Immigration, much-maligned by the anti-racist left. Quoted in Robert MILES, Annie PHIZACKLEA, White Man's Country: Racism in British Politics, London : Pluto Press, 1987, p. 57.

22. On why to call it "rivers of blood" is a problem, see Olivier ESTEVES, Stéphane PORION, The Lives and Afterlives of Enoch Powell : The Undying Political Animal, Abingdon : Routledge, 2019, p. 2.

23. See Erving GOFFMAN, The Presentation of Self in Everyday Life, Garden City (NY) : Anchor, 1959.

24. See Simon JEFFRIES, “Britain's Most Racist Election : The Story of Smethwick, 50 years on”, The Guardian, 15. 10. 2014. 
25. Elizabeth BUETTNER, “ 'This is Staffordshire not Alabama': Racial Geographies of Commonwealth Immigration in Early 1960s Britain", Journal of Imperial and Commonwealth History, 2014, Vol. 42 (4), p. 710-740.

26. Herbert KITSCHELT, The Radical Right in Western Europe : A Comparative Analysis, Ann Arbor : University of Michigan Press, 1997, p. 22.

27. Keith BANTING, Will KYMKICKA (eds.), The Strains of Commitment, Political Sources of Solidarity in Diverse Societies, Oxford : Oxford University Press, 2017, p. 11.

28. See Ibid.

29. Etienne Balibar in David Theo GOLDBERG (ed.), Anatomy of Racism, Minneapolis : University of Minnesota Press, 1990, p. 290.

30. Alan W. WOOLFE, Jyette KLAUSEN, "Identity Politics and the Welfare State", Social Philosophy and Policy, Vol. 14 (2), 1997, p. 240.

31. Quoted in Keith BANTING, Will KYMLICKA (eds.), op.cit, p. 8.

32. See Frederick COOPER, Decolonization and African Society: The Labor Question in French and British Africa, Cambridge : Cambridge University Press, 1996, p. 67.

33. On the odd episode when Marine Le Pen made a point about nativity scenes in town halls during the televised presidential debate in 2017, see Olivier ESTEVES, « Le Pen, les crèches et le centre commercial de Pawtucket», Libération, 06. 04. 2017.

34. "Racialism" was used in Britain in the 1960s, not "racism".

35. This tendency was largely mediatized by the conservative press. See See, for instance, Daily Mail, "Ghost Children : They Bilk the Taxman of Millions each Year", 09. 12. 1968 ; Daily Mail, "Stop These Immigrants Tax Frauds, Say Tories", 06. 12. 1968 ; Daily Telegraph, "3 Years Gaol for Immigrant in Tax Fraud", 01. 02. 1968 ; Daily Telegraph, "30 Million Pound Tax Fraud by Immigrant", 09. 08.0968; Daily Telegraph, "Tax Dodging, a 'Cancer and a Scandal' ", 21. 05. 1970.

36. On these points, see further details in E. J. B. ROSE (ed.), Colour and Citizenship : Report on British Race Relations, London : Institute of Race Relations / Oxford University Press, 1969, p. 446-7 ; p. 648.

37. See Abdellali HAJJAT, La Marche pour l'égalité et contre le racisme, Paris : Amsterdam, 2013, p. 27-8.

38. Staffordshire Record Office [hereafter SRO], Powell Papers [hereafter PP], respectively D3123/10 ; D3123/14; D3123/14 ; D3124/15 ; D4123/15 ; D4123/20.

39. See N. YUVAL-DAVIS, "Belonging and the Politics of Belonging", Patterns of Prejudice, Vol. 40 (3), 2006, p. 196-213.

40. On the connection between welfare chauvinism, race prejudice and gossiping, see Justin GEST, The New Minority: White Working-Class Politics in an Age of Immigration and Inequality, Oxford : Oxford University Press, 2016, p. 94-5.

41. SRO, PP, D3123/45 ; SRO, PP, D3123/57 ; SRO, PP, D3123/90.

42. See Gavin SCHAFFER, “' 'Till Death Us Do Apart' and the BBC: Racial Politics and the British Working Classes 1965-75”, Journal of Contemporary History, Vol. 45 (2), 2010, p. 465.

43. Although the overwhelming majority of Blacks hailed from the West Indies in those years, it was not infrequent to refer to them as "Africans". The African stereotype was also dramatized in the series Alf Garnett. See Ibid., p. 464.

44. This is based on discussions with Alexandre Dezé and Nonna Mayer, among other colleagues.

45. Nostalgia of French Algeria permeated such publication for a long time. See Todd SHEPPARD, «L'extrême droite et mai 1968, une obsession d'Algérie et de virilité », Clio, Vol. 29, 2009, p. 37-57. 46. Florian Foos and Daniel Bishof have recently argued that tabloid avoidance decreases Euroscepticism by analyzing the effects of the long-standing Sun boycott in Merseyside, see Financial Times, 26. 08. 2019.

47. See Pierre BOURDIEU, Questions de sociologie, Paris : Les Éditions de Minuit, 1984, p. 222-235. 
48. Support is nationwide, but areas of high levels of immigration are over-represented, as are counties at the periphery of the London conurbation (Berkshire, Buckinghamshire, Essex, Hertfordshire, Kent, Surrey). The South is more represented than the North, and much more than the North-East. On further details on the spatial-ethnocentric distribution of epistolary support to Enoch Powell, see Olivier ESTEVES, Inside the Black Box of 'White Backlash', Letters of Support to Enoch Powell (1968-9), forthcoming.

49. Olivier SCHWARZ, Le Monde privé des ouvriers, Paris : Presses Universitaires de France, 1990.

50. See Jacqueline BLONDEL, Bernard LACROIX, «Pourquoi votent-ils Front National ?», in Nonna MAYER, Pascal PERRINEAU, Le Front National à Découvert, Paris : Presses de Sciences-Po, 1996, p. 153.

51. See Ghassan HAGE, "Continuity and Change in Australian Racism", Journal of Intercultural Studies, Vol. 35(3), 2014, p. 233.

52. See Lawrence BLUM, I'm not Racist but...The Moral Quandary of Race, (Ithaca (N.Y.) : Cornell University Press, 2002), p. 124-134.

53. See for instance Alexandre DEZÉ, Le Front National : à la conquête du pouvoir?, Paris : Armand Colin, 2012, p. 46-8.

54. Quoted in Michelle LAMONT, The Dignity of Working Men, Morality and the Boundaries of Race, Class and Immigration, Cambridge (Mass) : Russell Sage Foundation \& Harvard University Press, 2000, p. 169.

55. Quoted in Emmanuelle COMTAT, Les Pieds-noirs et la politique: quarante ans après le retour, Paris : Presses de Sciences-Po, 2009, p. 253.

56. Cécile ALDUY, Stéphane WAHNICH, Marine Le Pen prise aux mots : décryptage du nouveau discours frontiste, Paris : Le Seuil, 2015, p. 41-46.

57. Ibid., p. 44.

58. This is despite the fact that Front National traditionally claims to be respectful of all French people whatever their race or religion. Citizenship (and the culturalisation of citizenship) is therefore at the heart of debate. On this self-presentation, see Daniel BIZEUL, Avec ceux du FN : un sociologue au Front National, Paris : La Découverte, 2003, p. 117.

59. Steve GARNER, Simon CLARKE, White Identities, A Critical Sociological Approach. London : Pluto Press, 2010, p. 9.

60. Joao CARVALHO, "The End of a Strategic Opening ? The BNP's window of opportunity in the 2000s and its closure in the 2010s", Patterns of Prejudice, Vol. 49 (3), 2015, p. 289, where it is claimed that "unemployment was found to be a weak predictor of support for the party".

61. Quoted in op.cit., p. 153.

62. This was in the historian's analysis of a text by Drieu La Rochelle. See Gérard NOIRIEL, Le Creuset français, Histoire de l'immigration, XIXème-XXème siècles, Paris : Seuil, 2006 [1988], p. 276.

63. See https://www.theguardian.com/global/video/2020/apr/15/you-clap-for-me-now-thecoronavirus-poem-onracism-and-immigration-in-britain-video (accessed 07.06. 2020).

\section{ABSTRACTS}

This article provides a comparison of welfare chauvinism responses in France and England, and demonstrates that there is in the latter a much deeper rootedness of such nativist dynamics, not only vis-à-vis France, but also when compared with other European countries. The article also 
interrogates top-down and bottom-up approaches in the social sciences, particularly as they apply to welfare chauvinism. The extreme interconnectedness between the two is not acknowledged in classical studies of "populism". Bringing together elite-driven discourses and grassroots interpellations of said elites, combining qualitative and quantitative data, the article underlines how deep-seated welfare chauvinist responses are in England, reaching back to at least the mid-1960s, whereas similar responses or dynamics (" seuil de tolérance ", etc.) would appear to be much more recent in France, whose major radical-right, nativist party (Rassemblement National) only fairly recently tapped into such feelings.

Cet article compare l'enracinement des thématiques de welfare chauvinism en France et en Angleterre, concluant à une exception anglaise en la matière, non seulement vis-à-vis de la France, mais sans doute dans un cadre européen plus global. En outre, l'article interroge les catégories de top-down et bottom-up dans les sciences sociales, arguant pour une prise en compte de l'interaction constante entre ces deux dynamiques, ce qu'une appréciation classique du "populisme" dans l'analyse du welfare chauvinism ne permet pas. Combinant des discours d'élite et des interpellations de la base (grassroots), des données qualitatives et quantitatives, l'article insiste sur le très profond enracinement en Angleterre de ces perceptions, schèmes interprétatifs, etc., qui remontent au moins au milieu des années 1960, là où des thématiques similaires ("seuil de tolérance», etc.) sont plus récentes en France, et ont été mobilisés électoralement par la droite radicale plus récemment.

\section{INDEX}

Mots-clés: État-Providence, ethnicité, droites radicales, France, Grande-Bretagne.

Keywords: welfare state, welfare chauvinism, top-down / bottom-up approaches, race prejudice, whiteness, post-coloniality, radical right, France, Britain

\section{AUTHOR}

\section{OLIVIER ESTEVES}

University of Lille 